\title{
Developing Learning Guidance and Counseling Program Based on Social and Emotional Learning in Senior High School
}

\author{
Muh. Farozin ${ }^{1 *}$, Luky Kurniawan ${ }^{2}$ \\ Department of Guidance and Counseling, Faculty of Education, Universitas Negeri Yogyakarta, \\ Colombo Street No. 1, Sleman, Special Region of Yogyakarta, Indonesia 55281 \\ Department of Guidance and Counseling, Faculty of Teacher Training and Education, Universitas Mercu Buana Yogyakarta, \\ Wates Street Km. 10, Bantul, Special Region of Yogyakarta, Indonesia 55753 \\ *Corresponding author, e-mail: farozin@uny.ac.id
}

Article received: April $8^{\text {th }} 2019$; revised: June 24 $4^{\text {th }} 2019$; accepted: June $25^{\text {th }} 2019$

\begin{abstract}
This research and development aims to develop a learning guidance and counseling program based on social and emotional learning (SEL) in senior high school, and find out the feasibility of the learning guidance and counseling program based on SEL. Approach used in this research was research and development. The development procedure refers to the procedure by Borg \& Gall. The two subject groups of program validation in this research and development were two expert validators who were competent in the learning guidance and counseling program and the school counselor group. Data collection instruments used were expert validation questionnaire; practitioner validation questionnaire; and focus group discussion (FGD) guidelines. The data analysis technique used was a quantitative descriptive analysis technique using categorization. The expert validation test obtained a score of 91.50 (good category) and the practitioner test obtained a score of 83.05 (good category). Based on the results of expert validation and practitioner test, learning guidance and counseling program based on SEL is feasible to be implemented.
\end{abstract}

Keywords: learning guidance and counseling program; SEL; senior high school

\begin{abstract}
Abstrak: Penelitian pengembangan ini bertujuan menghasilkan program bimbingan dan konseling belajar berbasis $S E L$ di sekolah menengah atas (SMA), dan mengetahui tingkat kelayakan program bimbingan dan konseling belajar berbasis $S E L$. Pendekatan yang digunakan dalam penelitian ini adalah penelitian dan pengembangan. Prosedur pengembangan mengacu pada prosedur Borg \& Gall. Dua kelompok subjek validasi program dalam penelitian dan pengembangan ini adalah dua validator ahli yang berkompeten dalam program bimbingan dan konseling belajar, serta kelompok guru bimbingan dan konseling. Instrumen pengumpulan data yang digunakan adalah kuesioner validasi ahli; kuesioner validasi praktisi; dan pedoman $F G D$. Teknik analisis data yang digunakan adalah teknik analisis deskriptif kuantitatif dengan menggunakan kategorisasi. Hasil uji validasi ahli diperoleh skor 91,50 (kategori baik) dan hasil uji praktisi diperoleh skor 83,05 (kategori baik). Berdasarkan hasil validasi ahli dan hasil uji praktisi tersebut, program bimbingan dan konseling belajar berbasis $S E L$ layak untuk diimplementasikan.
\end{abstract}

Kata kunci: program bimbingan dan konseling belajar; SEL; SMA

\section{INTRODUCTION}

Learning guidance and counseling program based on SEL integrates guidance and counseling that allow students to develop cognitive, affective and psychomotor competencies. Personal development competence is reflected in self-awareness; self-management; social awareness; relationship building

How to Cite: Farozin, M., \& Kurniawan, L., (2019). Developing Learning Guidance and Counseling Program Based on Social and Emotional Learning in Senior High School. Jurnal Kajian Bimbingan dan Konseling, 4(2), 47-52. https://doi.org/10.17977/um001v4i22019p047 
and responsible decision making skills (Babalis, Tsoli, Artikis, Mylonakou-Keke, \& Xanthakou, 2013; CASEL, 2003). The competence is expected to provide a basis for students for a better adaptation and support in achieving personal development tasks in the learning aspect.

School counselors always support the students in social and emotional learning to improve academic achievement by providing activities that advocate the learning program based on SEL. Therefore, they are working in collaboration with stakeholders and authorities to develop the social and emotional learning program for all students (Van Velsor, 2009).

According to the research on several senior high school guidance and counseling administrative tools conducted by the researcher, it can be seen that there is no guidance and counseling program based on SEL in senior high school and the existing programs have not been developed through a series of systematic processes, viz., planning, design, implementation, evaluation, and follow-up. On the other hand, the guidance and counseling programs in senior high school have been prepared based on needs assessment.

This research began with the problems faced by students in the learning process at school. The researcher conducted a preliminary study by interviewing the principal, school counselors, subject teachers and homeroom teachers at SMA Negeri 1 Depok Sleman Yogyakarta. The results show that some students are facing problems in the learning process, such as having no motivation to learn, unable to concentrate in learning, unable to manage time well; and mentally unprepared to face the national exam (UN).

The researcher distributed a needs analysis checklist of SEL competencies to 192 students in 10th grade. Based on the results, it is known that students in 10th grade need the following learning guidance and counseling themes or topics: preparing for higher education $83 \%$; choosing concentration area in senior high school $82 \%$; fostering enthusiasm in learning $82 \%$; concentration in learning $78 \%$; fostering empathy among peers in group learning activities $77 \%$; group learning activities $70 \%$; managing time in learning $74 \%$; discipline in learning $64 \%$; verbal communication skills in group study $74 \%$ and tips for making study group $58 \%$.

Several studies have been conducted to review the SEL program. Research by Gueldner \& Merrell (2011) found that SEL program may significantly improve students'knowledge competencies. Dracinschi (2012) pre-tested the SEL program that was adopted from England and developed in Romania. The conclusion of the research is a recommendation to integrate the SEL program into the education system in Romania. Reyes, Brackett, Rivers, Elbertson, \& Salovey (2012) tested the effects and quality of SEL program implementation on students' social and emotional competencies. The research concluded that the SEL program significantly improves students' social and emotional competencies. The difference between this research and the aforementioned research is that this research aims to produce a learning guidance and counseling program based on SEL in senior high school and find out the feasibility of the learning guidance and counseling program based on SEL. The researcher integrated SEL into the learning guidance and counseling program to improve students' academic achievement.

Based on above explanation, the researcher considered the development of learning guidance and counseling program based on SEL necessary. Therefore, the development of learning guidance and counseling program based on SEL is essential for supporting the students in achieving their personal development tasks in the learning aspect.

\section{METHOD}

The model used in the development of learning guidance and counseling program based on SEL was adapted and modified from the research and development model by Borg \& Gall (1984). The development process of the learning guidance and counseling program based on SEL consisted of three phases: preliminary study, development and validation. In the preliminary study phase, the researcher conducted a needs analysis, determined the research problem and conducted a literature study. In the development phase, the researcher planned and developed the initial program by arranging the learning guidance and counseling program based on SEL according to students' needs as well as concepts or theories. In the validation phase, the researcher conducted two stages of feasibility test, viz., expert validation and practitioner test. 
The subject of the needs analysis was 192 students, expert validation of the program involved two experts; practitioner test involving four school counselors and FGD involving four school counselors. Data collection method used in the study was the expert program questionnaire; practitioner test questionnaire; and FGD guidelines. Qualitative data analysis was done by grouping information, which was qualitative data, in the form of responses, input, criticisms and suggestions from experts, to revise the learning guidance and counseling program based on SEL in stage I. Results of the discussion as well as responses, input, criticism and suggestions from school counselors were used to revise the learning guidance and counseling program based on SEL in the revision stage II. Furthermore, the results of qualitative data analysis were taken into consideration for program revision. This research used a quantitative descriptive analysis, which is to analyze quantitative data obtained from the evaluation sheet obtained from expert validation and practitioner test.

\section{RESULTS}

The researcher validated the learning guidance and counseling program based on SEL to two experts who are competent in the learning guidance and counseling program, namely: Dr. Muhammad Nur Wangid, M.Si, and Dr. Budi Astuti, M.Si. The expert validation was conducted in June 2016. Data obtained from expert validation using closed questionnaire and suggestions for improvement on the developed learning guidance and counseling program based on SEL were quantitative data. Quantitative data from expert assessment on the learning guidance and counseling program based on SEL in senior high school are presented in table 1.

Table 1. Recapitulation of Expert Validation Analysis Results

\begin{tabular}{lccccc}
\hline No & Expert I & Expert II & Obtained Score & Percentage n/8 X 100\% & Category \\
\hline 1 & 4 & 4 & 8 & $100 \%$ & Good \\
2 & 4 & 3 & 7 & $87.5 \%$ & Good \\
3 & 4 & 2 & 6 & $75 \%$ & Moderate \\
4 & 3 & 2 & 5 & $62.5 \%$ & Moderate \\
5 & 3 & 4 & 7 & $87.5 \%$ & Good \\
6 & 4 & 4 & 8 & $100 \%$ & Good \\
7 & 4 & 4 & 8 & $100 \%$ & Good \\
8 & 4 & 4 & 8 & $100 \%$ & Good \\
9 & 4 & 3 & 7 & $87.5 \%$ & Good \\
10 & 3 & 4 & 7 & $87.5 \%$ & Good \\
11 & 4 & 3 & 7 & $87.5 \%$ & Good \\
12 & 4 & 4 & 8 & $100 \%$ & Good \\
13 & 3 & 3 & 6 & $75 \%$ & Moderate \\
14 & 4 & 4 & 8 & $100 \%$ & Good \\
15 & 4 & 3 & 7 & $87.5 \%$ & Good \\
16 & 4 & 4 & 8 & $100 \%$ & Good \\
17 & 4 & 4 & 8 & $100 \%$ & Good \\
18 & 4 & 3 & 7 & $87.5 \%$ & Good \\
19 & 3 & 4 & 7 & $87.5 \%$ & Good \\
20 & 4 & 4 & 8 & $100 \%$ & Good \\
21 & 4 & 4 & 8 & $100 \%$ & Good \\
22 & 4 & 3 & 7 & $87.5 \%$ & Good \\
23 & 4 & 3 & 7 & $87.5 \%$ & Good \\
24 & 4 & 4 & 8 & $100 \%$ & Good \\
25 & 4 & 4 & 8 & $100 \%$ & Good \\
& Total Assessment Score & $91.5 \%$ & Good \\
\hline
\end{tabular}


Table 2. Recapitulation of Practitioner Test Analysis Results

\begin{tabular}{cccccccc}
\hline No & $\begin{array}{c}\text { Practitioner } \\
\text { I }\end{array}$ & $\begin{array}{c}\text { Practitioner } \\
\text { II }\end{array}$ & $\begin{array}{c}\text { Practitioner } \\
\text { III }\end{array}$ & $\begin{array}{c}\text { Practitioner } \\
\text { IV }\end{array}$ & $\begin{array}{c}\text { Obtained } \\
\text { Score }\end{array}$ & $\begin{array}{c}\text { Percentage } \\
\text { n/16 X 100\% }\end{array}$ & Category \\
\hline 1 & 2 & 4 & 3 & 2 & 11 & $68.75 \%$ & Moderate \\
2 & 4 & 4 & 4 & 4 & 16 & $100 \%$ & Good \\
3 & 4 & 3 & 4 & 4 & 15 & $93.75 \%$ & Good \\
4 & 4 & 3 & 4 & 4 & 15 & $93.75 \%$ & Good \\
5 & 3 & 3 & 3 & 3 & 12 & $75 \%$ & Moderate \\
6 & 3 & 3 & 3 & 3 & 12 & $75 \%$ & Moderate \\
7 & 4 & 4 & 4 & 4 & 16 & $100 \%$ & Good \\
8 & 4 & 3 & 3 & 4 & 14 & $87.50 \%$ & Good \\
9 & 4 & 4 & 4 & 4 & 16 & $100 \%$ & Good \\
10 & 4 & 3 & 4 & 4 & 15 & $93.75 \%$ & Good \\
11 & 4 & 3 & 3 & 4 & 14 & $87.50 \%$ & Good \\
12 & 4 & 3 & 4 & 4 & 15 & $93.75 \%$ & Good \\
13 & 4 & 4 & 4 & 4 & 16 & $100 \%$ & Good \\
14 & 4 & 4 & 4 & 4 & 16 & $100 \%$ & Good \\
15 & 4 & 4 & 4 & 4 & 16 & $100 \%$ & Good \\
16 & 3 & 3 & 3 & 3 & 12 & $75 \%$ & Moderate \\
17 & 3 & 3 & 3 & 3 & 12 & $75 \%$ & Moderate \\
18 & 3 & 3 & 3 & 3 & 12 & $75 \%$ & Moderate \\
19 & 4 & 3 & 3 & 4 & 14 & $87.50 \%$ & Good \\
20 & 4 & 3 & 4 & 4 & 15 & $93.75 \%$ & Good \\
21 & 3 & 3 & 3 & 3 & 12 & $75 \%$ & Moderate \\
22 & 3 & 3 & 3 & 3 & 12 & $75 \%$ & Moderate \\
23 & 4 & 3 & 3 & 4 & 14 & $87.50 \%$ & Good \\
24 & 4 & 3 & 4 & 4 & 15 & $93.75 \%$ & Good \\
25 & 4 & 3 & 4 & 4 & 15 & $93.75 \%$ & Good \\
& & Total Assessment Score & & & $83.05 \%$ & Good \\
\hline
\end{tabular}

Based on the quantitative calculation in Table 1, the developed learning guidance and counseling program based on SEL in senior high school obtained an average score of $91.5 \%$, which is categorized good or feasible to be implemented according to the effectiveness criteria. Practitioner test is an assessment by practitioners on the learning guidance and counseling program based on SEL. The practitioner test produces quantitative data, which is obtained from practitioner assessment with a closed questionnaire. Quantitative data of practitioner assessment on the learning guidance and counseling program based on SEL in senior high school are presented in table 2. Based on the quantitative calculation in Table 2. the developed learning guidance and counseling program based on SEL in senior high school obtained an average score of $83.05 \%$, which is categorized good or feasible to be implemented according to the effectiveness criteria.

\section{DISCUSSION}

SEL is a learning process that is part of education developing social and emotional competencies for the success of students in school, family, society, workplace and life in general (Greenberg et al., 2003; Lilley, Oberle, \& Thompson, 2014; Osher et al., 2008; Zins, 2004). The five sets of SEL competencies that has been identified by the Collaborative for Academic, Social, and Emotional Learning (CASEL) are as follows: self-awareness, self-management, social awareness, relationship building and responsible decision making skills (CASEL, 2013; Elias, Zins, \& Weissberg, 1997; Oberle, Domitrovich, Meyers, \& Weissberg, 2016; Zins, Bloodworth, Weissberg, \& Walberg, 2007). 
The learning guidance and counseling program based on SEL has been validated by two experts in learning guidance and counseling program as well as school counselors group in senior high school. The results of the validation show that the program is feasible to be implemented. There were 25 aspect indicators assessed in the learning guidance and counseling program based on SEL in senior high school: clarity of rational; accuracy of legal basis; compatibility of guidance and counseling vision and school vision; compatibility of guidance and counseling missions and school missions; accuracy of description of needs; clarity of description of needs; clarity of learning guidance and counseling objectives; visibility of form of basic services; clarity of form of basic services; visibility of form of responsive services; clarity of form of responsive services; visibility of form of individual specialization and planning services; clarity of form of individual specialization and planning services; visibility of form of system support implementation; clarity of form of system support; clarity of scope of learning guidance and counseling; clarity of form of learning guidance and counseling program based on SEL; clarity of description of learning guidance and counseling program based on SEL; accuracy of themes and topics development; clarity of themes and topics development; clarity of facilities and infrastructure utilization; clarity of evaluation plan; clarity of reporting plan; clarity of follow-up plan; and clarity of budget.

Research by Babalis et al. (2013) show that the social and emotional learning program significantly improves students' social and emotional skills, as well as their academic behavior and performance. The results became one of the reasons behind the development of learning guidance and counseling program based on SEL. Social and emotional aspects became inseparable part of learning process. The two aspects may support the success of students' learning process.

Martinsone (2016) conducted a research on the description of content and implementation process of the social and emotional learning program that is developed based on Latvian culture. The developed social and emotional learning aims to develop students' social and emotional competencies in the learning process, as well as to combine social and emotional learning with academic.

Research by Waajid, Garner, \& Owen (2013) supports the significance of SEL policies and implementation in school. The role of school counselors in supporting students' social and emotional preparedness to learn at school highly supports the success of learning process and students' academic achievement. This is in line with the purposes of the learning guidance and counseling based on SEL developed by the researcher.

\section{CONCLUSION}

The development process of the learning guidance and counseling program based on SEL was done in three phases: preliminary study, development and validation. The validation results from two experts and four practitioners as well as input and suggestions from FGD show that the learning guidance and counseling program based on SEL is categorized good and feasible to be implemented. The structures of the learning guidance and counseling program based on SEL are: rational, legal basis, vision and mission, description of needs, objectives, program components, service sectors, operational plan, theme and topic development, facilities and infrastructure, reporting evaluation and follow-up, and budget.

\section{REFERENCES}

Babalis, T., Tsoli, K., Artikis, C. T., Mylonakou-Keke, I., \& Xanthakou, Y. (2013). The Impact of Social and Emotional Learning Programs on The Emotional Competence and Academic Achievement of Children in Greek Primary School. World Journal of Education, 3(6), 54-63.

Borg, W. R., \& Gall, M. D. (1984). Educational Research (4th ed). New York: Longman.

CASEL. (2003). Safe and Sound: An Educational Leader's Guide to Evidence-based Social and Emotional Learning (SEL) Programs. Chicago, IL.

CASEL. (2013). 2013 CASEL Guide: Effective Social and Emotional Learning Programs-Preschool and Elementary School Edition. Retrieved from https://casel.org/preschool-and-elementary-edition-casel-guide/

Dracinschi, M. C. (2012). Qualitative Aspects of The Instructive-Educational Process Specific for Social and Emotional Learning Programs. Educația Plus, 8(1), 135-159. 
Elias, M. J., Zins, J. E., \& Weissberg, R. P. (1997). Promoting Social and Emotional Learning: Guidelines for Educators. Ascd.

Greenberg, M. T., Weissberg, R. P., O’Brien, M. U., Zins, J. E., Fredericks, L., Resnik, H., \& Elias, M. J. (2003). Enhancing School-Based Prevention and Youth Development through Coordinated Social, Emotional, and Academic Learning. American Psychologist, 58(6-7), 466-474.

Gueldner, B., \& Merrell, K. (2011). Evaluation of A Social-Emotional Learning Program in Conjunction With The Exploratory Application of Performance Feedback Incorporating Motivational Interviewing Techniques. Journal of Educational and Psychological Consultation, 21(1), 1-27.

Lilley, J. L., Oberle, C. D., \& Thompson, J. G. (2014). Effects of Music and Grade Consequences on Test Anxiety and Performance. Psychomusicology: Music, Mind, and Brain, 24(2), 184-190. https://doi.org/10.1037/ pmu0000038

Martinsone, B. (2016). Social Emotional Learning: Implementation of Sustainability-Oriented Program in LATVIA. Journal of Teacher Education for Sustainability, 18(1), 57-68.

Oberle, E., Domitrovich, C. E., Meyers, D. C., \& Weissberg, R. P. (2016). Establishing Systemic Social and Emotional Learning Approaches in Schools: A Framework for Schoolwide Implementation. Cambridge Journal of Education, 46(3), 277-297.

Osher, D., Sprague, J., Weissberg, R. P., Axelrod, J., Keenan, S., Kendziora, K., \& Zins, J. E. (2008). A Comprehensive Approach to Promoting Social, Emotional, and Academic Growth in Contemporary Schools. Best Practices in School Psychology, 4, 1263-1278.

Reyes, M. R., Brackett, M. A., Rivers, S. E., Elbertson, N. A., \& Salovey, P. (2012). The Interaction Effects of Program Training, Dosage, and Implementation Quality on Targeted Student Outcomes for The RULER Approach to Social and Emotional Learning. School Psychology Review, 41(1), 82-99.

Van Velsor, P. (2009). School Counselors as Social-Emotional Learning Consultants: Where do We Begin? Professional School Counseling, 13(1), 50-58.

Waajid, B., Garner, P. W., \& Owen, J. E. (2013). Infusing Social Emotional Learning into the Teacher Education Curriculum. International Journal of Emotional Education, 5(2), 31-48.

Zins, J. E. (2004). Building Academic Success on Social and Emotional Learning: What does The Research Say? Teachers College Press.

Zins, J. E., Bloodworth, M. R., Weissberg, R. P., \& Walberg, H. J. (2007). The Scientific Base Linking Social and Emotional Learning to School Success. Journal of Educational and Psychological Consultation, 17(2-3), 191-210. 